\title{
Antimicrobial Importance of Medicinal Plants in Nigeria
}

\author{
Harriet U. Ugboko $\mathbb{D}^{1,2}$ Obinna C. Nwinyi, ${ }^{1,2}$ Solomon U. Oranusi, ${ }^{1,2}$ Toluwase H. Fatoki, ${ }^{3}$ \\ and Conrad A. Omonhinmin ${ }^{2,4}$ \\ ${ }^{1}$ Microbiology Unit, Department of Biological Sciences, Covenant University, Ota PMB 1023, Nigeria \\ ${ }^{2}$ Biotechnology Cluster, Covenant University, Ota PMB 1023, Nigeria \\ ${ }^{3}$ Translational Bioinformatics Unit, Department of Biochemistry, Federal University, Oye Ekiti, Ekiti State, Nigeria \\ ${ }^{4}$ Biology Unit, Department of Biological Sciences, Covenant University, Ota PMB 1023, Nigeria \\ Correspondence should be addressed to Harriet U. Ugboko; harrietugboko@gmail.com
}

Received 4 February 2020; Revised 10 July 2020; Accepted 9 September 2020; Published 22 September 2020

Academic Editor: Amal G. Al-Bakri

Copyright (c) 2020 Harriet U. Ugboko et al. This is an open access article distributed under the Creative Commons Attribution License, which permits unrestricted use, distribution, and reproduction in any medium, provided the original work is properly cited.

\begin{abstract}
Despite the success of antibiotic discovery, infectious diseases remain the second leading source of death worldwide, while the resistance to antibiotics is among the significant problems in the twenty-first century. Medicinal plants are very rich in phytochemicals which can be structurally optimized and processed into new drugs. Nigeria enjoys a diverse collection of medicinal plants, and joint research has ascertained the efficacy of these plants. Plants such as guava (Psidium guajava), ginger (Zingiber officinale), neem (Azadirachta indica), and moringa (Moringa oleifera) have been found to exhibit broad range of antimicrobial activities. Studies on Nigerian plants have shown that they contain alkaloids, polyphenols, terpenes, glycosides, and others with possible therapeutic potentials. The antimicrobial activities of some new compounds such as alloeudesmenol, hanocokinoside, orosunol, and 8-demethylorosunol, identified from medicinal plants in Nigeria, are not yet explored. Further investigation and optimization of these compounds will facilitate the development of new sets of pharmacologically acceptable antimicrobial agents. This review study revealed the efficacy of medicinal plants as an alternative therapy in combating and curtailing the development and survival of multidrug-resistant pathogens coupled with the toxic effects of some antibiotics. Due to enormous therapeutic possibilities buried in medicinal plants, there is a need for more research into unique fingerprints and novel compounds that can provide cure to the neglected tropical diseases (NTDs) of humans and animals facing Africa, especially Nigeria.
\end{abstract}

\section{Introduction}

Infectious diseases have been consistently found to be among the leading causes of threat to global health. The World Health Organization (WHO) in 2013 reported that infectious diseases accounted for $61.7 \%$ (5.9 million) of the 9.6 million deaths in the sub-Saharan African region. Plants with medicinal value have found application in healthcare from the olden years. Globally, there are evidence-based studies to verify the efficacy of medicinal plants, and some of these shreds of evidence have provided insights into the synthesis of plant-based compounds with therapeutics application [1]. The annual global market value of medicinal plant products has exceeded $\$ 100$ billion [2].
The "traditional or herbal medicines" are those originating from plant sources and are generally regarded as safe (GRAS) at the concoction dosage, based on their historical usage in various cultures [3]. Thus, plants remain the most abundant natural primary source of active drugs and are invaluable in the ethnomedical treatment of diverse ailments [4]. Medicinal plants are generally sources of various phytochemicals, some of which are usually responsible for their biological activities.

Traditional medicine as defined by the World Health Organization is the total of the knowledge, skills, and practices based on the theories, beliefs, and experiences indigenous to different cultures, whether explicable or not, used in the maintenance of health as well as in the 
prevention, diagnosis, improvement, or treatment of physical and mental illness. However, traditional, complementary medicine in Nigeria continues to thrive as it is commonly practised in other African nations as well as in Asia. Application of ethnomedicinal knowledge in the fields of biosciences for investigation of novel bioactive compounds as well as the polypharmacological formulation of plant extracts for use in primary healthcare has been the central interest in research [5].

Phytochemical screening of the medicinal plants is usually done against broad spectrum of microorganisms to ascertain their antimicrobial activities, based on the active constituents of the plants that are primarily secondary metabolites. The present occurrence of antimicrobial drug resistance by most bacteria has posed an enormous problem [6] and triggered the need for continuous research for better and safe therapeutic agents.

Most of the plants that found application in ethnomedicine have been documented based on their promising activities against multiple disease-causing microorganisms [7, 8]. Research efforts are expediting for better functional understanding of medicinal plants, and this has provided a model for about $25-50 \%$ of the marketed drugs [9]. Antimicrobial activities of useful plants vary; the majority act in synergy [10], reducing the side effect of synthetic drugs [11], while others act as quorum quenchers [12].

Moreover, this review summarized the salient information on the antimicrobial activity of medicinal plants in Nigeria and provided new bioactive components. This review explored research works on medicinal plants originating from Nigeria, and it highlights the constituents with potential therapeutics activities relevant to the treatment of microbial infections. The focus of this work is limited to the inhibitory effects of phytochemicals on diseases of microbial origin.

\section{Phytochemical Constituents of Medicinal Plants}

Medicinal plants contain bioactive organic chemical compounds often referred to as phytochemicals, which play a defensive role against major chronic diseases in both hostmetabolic or genetic dysfunctional disease and infectious disease, and found in grains, vegetables, fruits, and other plant products [13-16]. Phytochemicals perform intermediary metabolic activities, and they function as primary metabolites such as fats and sugars found in all plants, while secondary metabolites are found in a smaller range of plants and provide specialized functions.

Secondary metabolites are biomolecules produced for sustainability or adaptation of plants in the environment as a result of many factors, such as protection from drought, pollination, and predation, but are not required for immediate survival of the plants [17]. Secondary metabolites and pigments, because of their healing effects in humans are processed into drugs such as inulin (dahlias plant), morphine and codeine (poppy plant), quinine (cinchona plant), and digoxin (foxglove plant) [18].
Screening of chemical composition of medicinal plants revealed that they contain different bioactive compounds which include saponins, tannins, and alkaloids [19]. The main functional classes of phytochemicals with therapeutic potential include antioxidants, anticancer agents, immunitypotentiating agents, detoxifying agents, and neuropharmacological agents [17]. As shown in Figure 1, each of the functional classes of the phytochemicals consists of a wide range of compounds at varying potency and sometimes with multiple functions [16]. Plants produce unique arrays of phytochemicals that frequently belong to existing biochemical motifs [20]. Among the bioactive compounds, triterpenoids provide anti-inflammatory activity and tannins possess astringent, anti-inflammatory, and antimicrobial activity properties [21]. Saponins often have medicinal features as blood cleansers, expectorants, and antibiotics. At the same time, alkaloids have significant effects on the central nervous system (CNS), and glycosides are known for their ability to increase the forces of systolic concentration [22].

2.1. Phytochemical Screening. The active ingredients of medicinal and aromatic plants extracts are in the roots, stems, bark, leaves, or flowers [17]. Most times, the actions of these active ingredients on the human CNS could be associated with ecological roles or biochemical identities in other plants and higher animals [23]. The significant steps to utilize these biologically active compounds from plant resources involve the extraction, primary screening, isolation, purification, and characterization as well as pharmacological and toxicological analyses [24].

Pharmaceutically, the extraction involves the separation of constituents of plant and microorganism tissues using selective buffer solution or solvents according to standard protocols $[25,26]$. The crucial parameters that can influence the quality of an extract from the plant include parts used as a sample (leaf, bark, or root), solvent and its concentration used for extraction, and extraction method, while the effect of chemical constituents obtained from the extract depends on the nature of the plant material, its source, the extent of processing, and level of moisture, as well as particle size [27]. Factors that can influence the secondary metabolite composition and quantity in an extract include type and time of extraction, nature and concentration of the solvent, processing temperature, and polarity of analytes [27].

Different techniques, which include varieties of column chromatography, gas chromatography-mass spectrometry (GC-MS), Fourier-transform infrared spectroscopy (FTIR), ultraviolet (UV) spectrophotometry, and nuclear magnetic resonance (NMR), are often used stepwise for purification, identification, and structural characterization of various groups of phytochemical compounds in plants extracts $[22,24,28]$.

2.2. Effect of Processing on Phytochemicals. The processing of medicinal plants can alter antioxidant activity by increase or decrease in efficacy. Methods of processing of medicinal plants can impact on the phytochemical constituent 


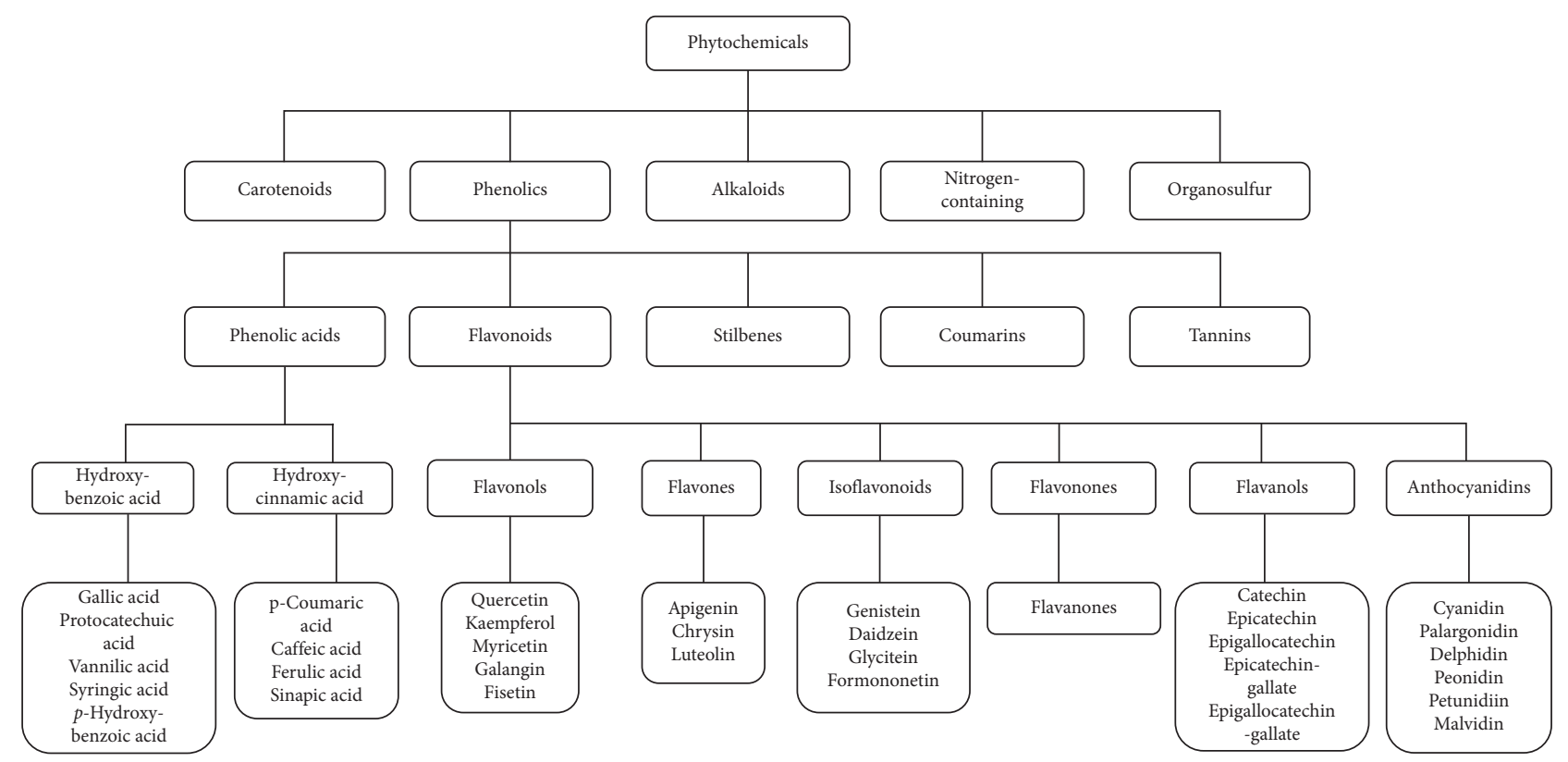

FIgURE 1: Classification of phytochemicals adapted from [15].

availability for pharmacological effect. Baba and Onanuga [29] found that different methods of processing sandpaper leaf (Ficus exasperata) extracts inhibited arginase and angiotensin-1-converting enzymes (ACE) activities in a dosedependent manner. Moreover, their result showed that the soaking method produced significantly higher inhibition of both enzymes than other methods which include hand maceration, boiling, and blending. Previous studies show that the health benefits of the medicinal plant in mono- or poly-formulations are often a result of complex mixtures of phytochemicals in a holistic form which synergistically modulates multiple targets to produce overall therapeutic actions due to combined antioxidant properties [30-32]. The effects of processing methods (blanching, cooking or thermal processing, dehydration or drying, extrusion, and irradiation), other nonthermal processing (storage, carbon dioxide treatment), and other ingredients in the formulation on the phytochemicals have been extensively reviewed by [15]. However, during processing, naturally occurring antioxidants often undergo degradation such as Strecker degradation, as well as reactions such as Maillard reaction, leading to the formation of new compounds with lower or higher antioxidant activity, thereby accounting for the differences in the total phenolic contents and antioxidant activities in the processed when compared to unprocessed foods [33].

\section{Medicinal Plants in Nigeria with Antimicrobial Activities}

Despite the success of antibiotic discovery, infectious diseases are consistently ranked second among causes of death worldwide [34]. The pursuit of new compounds that have therapeutic potential for infectious diseases with no existing remedy such as Lassa fever and others focuses mainly on plants as the best reservoir of drug compounds (Table 1). The microbial resistance to antibiotics is among the significant problems in the twenty-first century and has necessitated the need for a continuous search for more potent and safe therapeutic agents [7].

3.1. Antibacterial Activity. Tuberculosis (TB) is a lifethreatening disease caused by various Mycobacterium species and has been ranked among the leading causes of human death in the developing nations [51]. In 2013, WHO reported that approximately 8.6 million people incurred TB and 1.3 million died from it, with an estimated 450,000 new cases of multidrug-resistant TB worldwide. Chronic cough is a feature of many common respiratory diseases with the percentage of global occurrence in Oceania (18.1\%), Europe (12.7\%), America (11.0\%), Asia (4.4\%), and Africa (2.3\%) [52]. Diarrhea is a killer disease; according to 2015 observatory data of WHO, the occurrence of childhood mortality in developing nations due to diarrhoeal disease was between $9 \%$ and $34 \%$. Many enteric bacterial pathogens are responsible for diarrhea, which include bacteria such as Vibrio cholera, Campylobacter jejuni, Helicobacter pylori, Salmonella typhi or paratyphi, Shigella flexneri, Clostridium difficile, and Shiga toxin-producing Escherichia coli.

Findings of $[53,54]$ stated that the root and leaf extracts of Terminalia glaucescens show appreciable activity against E. coli and S. typhi [53]. The methanol extracts of three Nigerian medicinal plants have antimicrobial activity against five clinical bacterial isolates comprising two Gram-positive bacteria (Bacillus subtilis and Staphylococcus aureus) and three Gram-negative bacteria (Pseudomonas aeruginosa, E. coli, and Klebsiella pneumonia) organisms [7]. Acetone and ethanol extracts 
TABLE 1: Summary of selected antimicrobial medicinal plants in Nigeria.

\begin{tabular}{|c|c|c|c|}
\hline SN & Botanical name of the medicinal plant & $\begin{array}{l}\text { Major therapeutic } \\
\text { application }\end{array}$ & References \\
\hline 1 & $\begin{array}{c}\text { Argemone mexicana, Ficus exasperate, Persia Americana, Alchornea laxiflora, Crinum } \\
\text { jagus, Adansonia digitate, Citrullus colocynthis, Cola nitida, Dorstenia prorepens, } \\
\text { Echinacea purpurea, Spondias mombin, Annona senegalensis, Vernonia amygdalina, } \\
\text { Thymus vulgaris }\end{array}$ & Antibacterial & [35-40] \\
\hline 2 & $\begin{array}{l}\text { Enantia chlorantha, Azadirachta indica, Justicia flava, Landolphia owariensis, Cassytha } \\
\text { filiformis, Morinda lucida, Allamanda cathartica, Allophylus africanus, Clerodendrum } \\
\text { capitatum, Bixa Orellana, Senna alata }\end{array}$ & $\begin{array}{l}\text { Antibacterial antiparasitic } \\
\text { antifungal }\end{array}$ & {$[35,37,40-43]$} \\
\hline 3 & $\begin{array}{c}\text { Mangifera indica, Myristica fragrans, Cajanus cajan Gossypium arboretum, } \\
\text { Amaranthus spinosus, Heeria insignis, Momordica charantia, Diospyros monbuttensis, } \\
\text { Morinda lucida, Calotropis procera }\end{array}$ & Antiparasitic & {$[35,37,44,45]$} \\
\hline 4 & Ageratum conyzoides, Macaranga barteri, Mondia whitei & Antiviral & {$[46-50]$} \\
\hline
\end{tabular}

of bark of Azadirachta indica (A. Juss.), at a concentration of 25-400 mg/ml, showed significant antibacterial activity on all 14 strains of multidrug-resistant Salmonella typhi with zone diameter of 18-31 mm [55].

An investigation of the activity of aqueous and ethanolic extracts of Zingiber officinale and Allium sativum extracts on selected foodborne pathogens (Salmonella species, Bacillus cereus, E. coli, and $S$. aureus) showed multidrug resistance. $E$. coli was sensitive to aqueous extracts, but $S$. aureus and Salmonella species were sensitive to ethanol extracts [56]. The alcoholic extracts from the leaves of two Diospyros spp. (D. barteri and D. monbuttensis) showed potent antibacterial activity against a wide range of Gram-positive and Gramnegative bacteria, while two fungal species investigated in the study, Aspergillus niger and Candida albicans, were resistant to the extracts of both Diospyros spp. [57].

The result of in vitro study of water, methanol, chloroform, and petroleum ether extracts of Senna alata flowers, which examined antimicrobial properties at a final concentration of $500 \mu \mathrm{g} / \mathrm{mL}$, showed antimicrobial activities against clinical isolates of S. aureus, C. albicans, E. coli, Proteus vulgaris, P. aeruginosa, and B. subtilis [58]. Heeria insignis O. Ktze, a member of the family Anacardiaceae, is an indigenous African shrub used in the treatment of diarrhea, schistosomiasis, and venereal diseases. The methanol and dichloromethane extracts of the leaves of $H$. insignis possessed antibacterial and antidiarrheal activities, while methanol showed a more significant antibacterial activity than dichloromethane [59]. However, aqueous extracts of the stem bark of Spondias mombin have outstanding anthelmintic activity at low concentrations [3].

Preliminary investigation of the in vitro vibriocidal activities of three medicinal plants (traditional Ogi-tutu, Psidium guajava, and Vernonia amygdalina), using agar cup diffusion assay, showed that $V$. amygdalina has the highest ameliorative effects in the deterrence and cure of $V$. cholerae infection [60]. Moreover, a study has revealed the antibacterial property of $T$. vulgaris on multiple antibiotic-resistant Vibrio fluvialis and Vibrio parahaemolyticus isolated from shrimps using agar diffusion method [61]. The examination of Argemone mexicana L. for antimicrobial activity showed that the aerial and root extracts inhibited $B$. subtilis and K. pneumoniae, but $P$. aeruginosa and $S$. aureus were not prone to the aerial and root extracts.
In Nigerian ethnomedicine, Annona senegalensis Pers. (Annonaceae) has been used for the treatment of infectious diseases. Okokon et al. [62] investigated A. senegalensis using the GC-MS and agar-well-diffusion method and found that lipophilic fraction and kaurenoic acid from A. senegalensis root bark showed potent antibacterial activity. Furthermore, the results of in vivo and in vitro model investigations of the antidiarrheal properties of the stem bark extract of $A$. senegalensis using mice and isolated rabbit jejunum showed maximum inhibition at a dose of $10 \mathrm{mg} / \mathrm{kg}$. At the same time, intestinal transit time decreased at concentrations of $0.2-3.2 \mathrm{mg} / \mathrm{ml}$, and the extract lessened spontaneous contractions of the jejunum [63].

Ficus exasperata Vahl-Holl (Moraceae) leaves in West Africa are used for the treatment of infectious diseases and inflammatory conditions. However, a more thorough phytochemical analysis of the ethnomedicinal uses of $F$. exasperata has identified new compounds: apigenin C-8 glucoside, isoquercitrin-6$O$-4-hydroxybenzoate, and quercetin-3-O- $\beta$ - rhamnoside, as some of the constituents of this plant that inhibited the growth of Gram-positive organisms only [64].

3.2. Antimalarial Activity. Malaria, a significant threat to global health, is responsible for the death of millions of people predominantly in sub-Saharan Africa. The occurrence of multidrug-resistant malaria parasites has triggered efforts to develop combined formulations (such as artemether-lumefantrine and sulfadoxine-pyrimethamine) and continuous research toward discovering better therapeutics. An in vitro study by Oladele [65] on the sensitivity pattern of Plasmodium falciparum to Diospyros monbuttensis ("Egun eja"), Momordica charantia ("Ejirin"), and Morinda lucida ("Oruwo") recorded the lowest antiplasmodial activity with the ethanolic extract of $M$. lucida $\left(\mathrm{IC}_{50}=25 \mathrm{nM}\right)$ while $D$. monbuttensis recorded the highest activity $\left(\mathrm{IC}_{50}=3.2 \mathrm{nM}\right)$.

A study on the anticoccidial effect of $M$. lucida on Eimeria parasites has suggested its potential as an anticoccidial drug for veterinary purposes, especially the poultry birds [66]. Furthermore, the triterpenes and phytosterols derived from $M$. lucida showed high binding affinity toward the selected histone deacetylases (class I HDAC and HDAC7 isoforms) and exhibited good druggable characteristics [67]. 
Oladele [65], investigated the antiplasmodial activity of crude $\mathrm{n}$-hexane and ethanolic extracts of $M$. oleifera seeds using the cold extraction method and found the highest parasite inhibition activity in crude ethanolic extract. Besides, Landolphia owariensis P.Beauv., a member of the family Apocynaceae, is used in southeast Nigeria for the treatment of malaria. A study has shown that methanol fractions of $L$. owariensis leaf in early, established, and residual infections in Plasmodium berghei-infected albino mice have the most significant antiplasmodial activity in all the models carried out, due to alkaloids, flavonoids, saponins, and tannins present in the fractions [68].

Allamanda cathartica and Bixa orellana are antimalarial plants [69]. Moreover, Alchornea laxiflora (Benth.), a member of the family Euphorbiaceae, is used traditionally in the treatment of malaria in Nigeria. Furthermore, the study has shown that root extract $A$. laxiflora exerted significant antimalarial activity against $P$. berghei infection while ethyl acetate fraction exerted the highest activity against chloroquine-sensitive (Pf3D7) and -resistant (PfINDO) strains of P. falciparum infection in mice [70]. Enantia chlorantha has significant utilization in traditional medicine for the treatment of several diseases which include malaria. However, another study has suggested that oral administration of $E$. chlorantha at relatively high doses may produce severe toxic effects [71]. A study on the acute and subacute toxicity of the medicinal plant $E$. chlorantha carried out in mice showed a mean lethal dose $\left(\mathrm{LD}_{50}\right)$ of $0.7 \mathrm{~g} \cdot \mathrm{kg}^{-1}$ for ethanolic but $43.65 \mathrm{~g} \cdot \mathrm{kg}^{-1}$ for aqueous preparations [72].

Cajanus cajan (L.) is a member of the family Fabaceae and possesses antimalarial properties. The result of the in vitro investigation of crude methanolic extract of C. cajan leaves, using the multiresistant strain of $P$. falciparum (K1) and combination of chromatographic techniques, identified cajachalcone $\left(2^{\prime}, 6^{\prime}\right.$-dihydroxy-4-methoxy chalcone) from the ethyl acetate fraction, as one of the biologically active constituents [73].

Azadirachta indica (A. Juss.) belongs to the family Meliaceae, which is a common plant especially in Africa, and extracts from parts of this plant have shown pharmacological activities which include antiplasmodial activity [74]. However, the antimalarial activity of $A$. indica is yet to be fully ascertained, this calls for in-depth research on antimalarial activity of $A$. indica. However, an in silico study [75] has identified margolonone, nimbinone, and nimbione as the highest functional compounds that can modulate the activity of $P$. falciparum heat shock protein 90 (PfHsp90).

Research has shown that Allophylus africanus extracts curbed parasitemia caused by intraperitoneal administration of erythrocytes of $P$. berghei (NK-65) in mice, and it was found that flavonoids, saponins, tannins, and carbohydrates are predominant in all parts of A. africanus [76]. Moreover, four new compounds, hanocokinoside, allotaraxerolide, alloeudesmenol, and alloaminoacetaldehyde, have been identified as some of the chemical constituents of A. africanus [42]. Three lignans, (+) isolariciresinol, helioxanthin, and justicinol, have been isolated from Justicia flava VAHL leaves [77]; in addition, 8-demethylorosunol and orosunol were reported as two new 1-aryl-2, 3-naphthalide lignans from J. flava root [78]. Therefore, further investigation and optimization of these new compounds can help in the design and production of a new set of efficacious and safe antimicrobial agents.

3.3. Antifungal Activity. Infections caused by fungi are termed fungal infections or mycoses. Fungal infections have been considered a serious health problem and life-threatening diseases in recent years, especially in immunodeficiency conditions $[8,79]$. Severe fungal diseases result from other health challenges such as human immunodeficiency virus (HIV), asthma, cancer, organ transplantation, and corticosteroid treatments [80]. In Nigeria, fungal infections (cryptococcal antigenemia, subclinical histoplasmosis) have been implicated in HIV/AIDS patients and neonatal intensive care babies [81, 82]. In Cameroun, esophageal candidiasis, cryptococcal meningitis, Pneumocystis pneumonia, disseminated histoplasmosis, and invasive aspergillosis were prevalent in adults, while tinea capitis was prevalent among school children ([83]. In Mozambique, disseminated Emergomyces and recurrent Candida vulvovaginitis were common among HIV patients [84]. Some hospitalized patients are at risk of contracting fungal infections [85]. Besides, emerging and reemerging fungal infections due to recent therapies for autoimmune and cancer-related diseases (hematopoietic stem cell transplant) are becoming public health concern [86, 87]. Different parts of Calotropis procera, a flowering plant that belongs to the family Asclepiadaceous, have been utilized in traditional medicine for the treatment of infections which include eczema, cutaneous infections, leprosy, and syphilis, as well as malaria. In a study on antifungal activity of C. procera, there was complete inhibition of Microsporum and Trichophyton species after ten days of inoculation with water extract at different concentrations [88].

Crude methanolic extract of Spondias mombin (bark and leaves) was found to exhibit anticandidal effects with diameters of $11.00 \pm 0.47 \mathrm{~mm}$ and $15.00 \pm 0.47 \mathrm{~mm}$, respectively. The extracts have varying degrees of phytochemical compositions such as terpenoids, alkaloids, glycosides, saponin, and flavonoids [89]. Psidium guajava extracts were active on Candida albicans isolates from caries infected patients [90]. Additionally, Alchornea laxiflora leaf extracts have antibacterial and antifungal activities due to flavonoids, alkaloids, saponins, tannins, and reducing sugars as major phytochemicals [36].

3.4. Antiviral Activity. Human immunodeficiency virus type 1 (HIV-1) encodes reverse transcriptase which functions in the process of the viral genome reverse transcription, a fundamental step in the HIV-1 replication cycle and promising target in the antiretroviral drug development [91]. A study conducted in Nigeria [47] on the antiviral activities of 27 medicinal plant extracts, belonging to 26 different plant species, against echovirus 7, 13, and 19 serotypes (E7, E13, and E19, respectively) revealed the highest antiviral activity from methanolic extract of Macaranga barteri leaves on E7 and E9, respectively, followed by 
Ageratum conyzoides leaves extract on E7 and E19 and Mondia whitei leaves extract on E7 and E19. In China, Rheum palmatum and Rheum officinale extracts along with their main single isolated constituents' anthraquinone derivatives inhibited both $\mathrm{HIV}-1$ reverse transcriptase-associated DNA polymerase (RDDP) and ribonuclease $\mathrm{H}$ activities [92]. The screening of some plants showed antiretroviral activities. For instance, Ancistrocladus korupensis [93] and Ancistrocladus congolensis [94] produced michellamine A and B [95], Ancistrocladus congolensis [94].

\section{Mechanisms of Action of Medicinal Plants}

The rare occurrence of infectious diseases in wild plants serves as a fundamental indication of the presence of competent defence mechanisms. Different mechanisms of action through which phytochemicals can exert antimicrobial activities include (i) inhibition of the activity of enzymes and toxins, (ii) damage of the bacterial membrane, (iii) suppression of virulence factors, (iv) formation of biofilm, (v) inhibition of protein synthesis, and (vi) quorum quenching [96]. The mode of action of tannins is based majorly on their ability to bind proteins, thereby inhibiting cell protein synthesis [97-99]. The intervention of quorum sensing is in three levels: (i) signal synthesis, (ii) signal sequestration, and (iii) signal reception [100].

\subsection{Synergistic Activity of Antimicrobial Medicinal Plants and} Antibiotics. Antibiotics have been effective in treating infectious diseases, but resistance to these drugs has led to the emergence of new and the reemergence of old infectious diseases. The development of resistance to antibiotics in bacteria has been found possible due to three reasons: (i) direct destruction or modification of the antibiotic by enzymes produced by the organism, (ii) modification of target resulting in a reduction in the efficiency of binding of the drug; and (iii) efflux of antibiotic from the cell [101-103].

One of the strategies used to overcome resistance mechanisms in combination therapy includes combined active drug or polyherbal formulations [10]. The use of natural products in combination with antibiotics to enhance treatment efficacy is a new strategy developed to overcome the problem of antibiotics resistance [104]. The presence of many bioactive compounds in a medicinal plant provides a synergistic therapeutic effect, but when used simultaneously with standard drugs, they often improve the activity of the drug and will confront problems of toxicity and overdose [13].

A combination of Helichrysum pedunculatum leaf extracts with antibiotics used against wound infection associated bacteria resulted in about 60\% synergistic effect. Hemaiswarya et al. [105] investigated the antiplasmodial activities of various combinations of Murraya koenigii leaf, Artocarpus altilis stem bark [2], Nauclea latifolia root, and Enantia chlorantha stem bark, with standard drugs. They observed a significant reduction in the protective, chemosuppressive, and curative actions of N. latifolia coadministered with standard drugs. Besides, N. latifolia or $M$. koenigii in combination with other plants produced a synergistic effect, unlike using each plant alone. Furthermore, E. chlorantha with $A$. altilis or $N$. latifolia enhanced their respective prophylactic or curative activities and served as promising combinations for the treatment of malaria [2]. Coadministration of Carica papaya and Vernonia amygdalina plants in ameliorating Plasmodium infection in mice showed synergistic effects with significant percentage suppression of parasite load within three days of clinical therapy [106].

\section{Future of Medicinal Plants}

The future of medicinal plants is promising, considering the vast number of medicinal plants that are yet to be selected and investigated for their phytochemical compositions. Medicinal plants have provided an avenue for understanding the scaffold for synthetic drug design and development. In addition, the future of medicinal plants will influence the medical practice, considering the occurrence of new pathogens and diseases, which calls for alternative or complementary medicine [11]. The rising tide in antibiotic resistance by microorganism has raised significant concern in the medical field and, thus, an urgent demand for the discovery of safe, natural compounds in this postgenomic era. The use of medicinal plants as nutraceuticals and functional foods is on the increase, as means of ensuring preventive medicine and finding a solution to this global concern of evolution of drug-resistant microorganisms [1].

\section{Conclusion}

This review report has revealed the efficacy of medicinal plants as an alternative therapy in tackling the development and spread of multidrug-resistant pathogens coupled with the toxic effects of some antibiotics. However, this study shows the lack of adequate characterization of the chemical composition of the antimicrobial medicinal plants in Nigeria. Only a few of the medicinal plants studied in Nigeria have their bioactive components investigated using advanced analyses such as GC-MS and HPLC. The absence of such analyses makes the claims from ethnomedicinal and phytochemical screening studies invalidated. Due to enormous therapeutic possibilities buried in the medicinal plants, there is a need for research into unique fingerprints and novel compounds that can provide cure to the neglected tropical diseases (NTDs) endemic in Africa and especially in Nigeria. Moreover, there is a need for innovative investigation of novel natural bioactive compounds for the development of chemical libraries useful for drug discovery and development pipelines. A better understanding of the underlying mechanism of the synergy of two or more combinations of phytochemicals at a molecular level will decrease the use of antibiotics and help to prevent and overcome drug-resistant pathogens.

\section{Conflicts of Interest}

The authors declare that they have no conflicts of interest regarding the publication of this paper. 


\section{Acknowledgments}

The authors would like to appreciate Covenant University for defraying the cost of this publication.

\section{References}

[1] K. Dhama, R. Tiwari, S. Chakrabort et al., "Evidence based antibacterial potentials of medicinal plants and herbs countering bacterial pathogens especially in the era of emerging drug resistance: an integrated update," International Journal of Pharmacology, vol. 10, no. 1, pp. 1-43, 2014.

[2] A. Singh, E. Ogunbodede, and A. Onayade, "The role and place of medicinal plants in the strategies for disease prevention," African Journal of Traditional, Complementary and Alternative Medicines.vol. 10, no. 5, pp. 210-229, 2013.

[3] D. E. Uzodimma, "Medico-ethnobotanical inventory of ogii, okigwe imostate, south eastern Nigeria," Global Journal of Medicinal Plants Research, vol. 2, no. 2, pp. 30-44, 2013.

[4] G. I. Olasehinde, O. I. Ayanda, A. A. Ajayi, and A. P. Nwabueze, "In-vivo antiplasmodial activity of crude n-hexane and ethanolic extracts of Moringa oleifera (lam.) seeds on Plasmodium berghei," International Journal of Medicinal Plants Research, vol. 1, no. 5, pp. 50-54, 2012.

[5] A. O. Adeeyo, J. Odiyo, and K. Odelade, "Chemical profiling and antimicrobial properties of phyto-active extracts from Terminalia glaucescens stem against water microbial contaminants," The Open Biotechnology Journal, vol. 12, no. 1, 2018.

[6] D. Kpadonou, S. E. Kpoviessi, J. Bero et al., "Chemical composition, in vitro antioxidant and antiparasitic properties of the essential oils of three plants used in traditional medicine in Benin," Journal of Medicinal Plants Research, vol. 13, no. 16, pp. 384-395, 2019.

[7] P. C. Chikezie, C. O. Ibegbulem, and F. N. Mbagwu, "Bioactive principles from medicinal plants," Research Journal of Phytochemistry, vol. 9, no. 3, pp. 88-115, 2015.

[8] O. O. Ogbole, T. E. Akinleye, P. A. Segun, T. C. Faleye, and A. J. Adeniji, "In vitro antiviral activity of twenty-seven medicinal plant extracts from southwest Nigeria against three serotypes of echoviruses," Virology Journal, vol. 15, no. 1, p. 110, 2018.

[9] P. A. Segun, O. O. Ogbole, T. E. Akinleye, T. O. Faleye, and A. J. Adeniji, "In vitro anti-enteroviral activity of stilbenoids isolated from the leaves of Macaranga barteri," Natural Product Research, vol. 74, no. 1, pp. 1-5, 2019.

[10] I. A. Oladosu, S. O. Balogun, and L. Zhi-Qiang, "Chemical constituents of Allophylus africanus," Chinese Journal of Natural Medicines, vol. 13, no. 2, pp. 133-141, 2015.

[11] M. M. A. El-Ghani, "Traditional medicinal plants of Nigeria: an overview," Agriculture and Biology Journal of North America, vol. 7, no. 5, pp. 220-247, 2016.

[12] F. Moussaoui and T. Alaoui, "Evaluation of antibacterial activity and synergistic effect between antibiotic and the essential oils of some medicinal plants," Asian Pacific Journal of Tropical Biomedicine, vol. 6, no. 1, pp. 32-37, 2016.

[13] R. Khan, B. Islam, M. Akram et al., "Antimicrobial activity of five herbal extracts against multi drug resistant (MDR) strains of bacteria and fungus of clinical origin," Molecules, vol. 14, no. 2, pp. 586-597, 2009.

[14] B. Nayak, R. H. Liu, and J. Tang, "Effect of processing on phenolic antioxidants of fruits, vegetables, and grains-a review," Critical Reviews in Food Science and Nutrition, vol. 55, no. 7, pp. 887-918, 2015.
[15] A. A. Gbolade and A. A. Adeyemi, "Anthelmintic activities of three medicinal plants from Nigeria," Fitoterapia, vol. 79, no. 3, pp. 223-225, 2008.

[16] F. Esposito, I. Carli, C. Del Vecchio et al., "Sennoside A, derived from the traditional Chinese medicine plant rheum L., is a new dual HIV-1 inhibitor effective on HIV-1 replication," Phytomedicine, vol. 23, no. 12, pp. 1383-1391, 2016.

[17] D. O. Kennedy and E. L. Wightman, "Herbal extracts and phytochemicals: plant secondary metabolites and the enhancement of human brain function," Advances in Nutrition, vol. 2, no. 1, pp. 32-50, 2011.

[18] A. Agunu, A. A. Ahmadu, S. O. Afolabi, A. U. Yaro, J. O. Ehinmidu, and Z. Mohammed, "Evaluation of the antibacterial and antidiarrhoeal activities of Heeria insignis," Indian Journal of Pharmaceutical Sciences, vol. 73, no. 3, pp. 328-332, 2011.

[19] A. C. Ezike, C. H. Okonkwo, P. A. Akah, T. C. Okoye, C. S. Nworu et al., "Landolphia owariensis leaf extracts reduce parasitemia in Plasmodium berghei-infected mice," Pharmaceutical Biology, vol. 54, no. 10, pp. 2017-2025, 2016.

[20] G. Singh, E. Tamboli, A. Acharya, C. Kumarasamy, K. Mala, and P. Raman, "Bioactive proteins from solanaceae as quorum sensing inhibitors against virulence in Pseudomonas aeruginosa," Medical Hypotheses, vol. 84, no. 6, pp. 539-542, 2015.

[21] D. A. Akinpelu, E. O. Abioye, O. A. Aiyegoro, O. F. Akinpelu, and A. I. Okoh, "Evaluation of antibacterial and antifungal properties of Alchornea laxiflora (benth.) pax. \& hoffman," Evidence-Based Complementary and Alternative Medicine, vol. 2015, Article ID 684839, 13 pages, 2015.

[22] O. J. Olaitan, S. U. Wasagu, A. A. Adepoju-Bello, K. U. Nwaeze, and A. Olufunsho, "Preliminary anti-fungal activity of the aqueous bark extract of Calotropis procera (asclepiadaceae)," Nigerian Quarterly Journal of Hospital Medicine, vol. 23, no. 4, pp. 338-341, 2013.

[23] O. Ukamaka, N. Paul, and E. Ikechi, "Antiviral effects of Nauclea latifolia on newcastle disease virus (NDV)," Sky Journal of Microbiology Research, vol. 3, pp. 1-5, 2015.

[24] A. Corona, T. Masaoka, G. Tocco, E. Tramontano, and S. F. Le Grice, "Active site and allosteric inhibitors of the ribonuclease $\mathrm{H}$ activity of HIV reverse transcriptase," Future Medicinal Chemistry, vol. 5, no. 18, pp. 2127-2139, 2013.

[25] U. Udochukwu, F. I. Omeje, I. S. Uloma, and F. D. Oseiwe, "Phytochemical analysis of vernonia amygdalina and Ocimum gratissimum extracts and their antibacterial activity on some drug resistant bacteria," American Journal of Respiratory and Critical Care Medicine, vol. 3, no. 5, pp. 225-235, 2015.

[26] O. A. Aiyegoro, A. J. Afolayan, and A. I. Okoh, "Synergistic interaction of Helichrysum pedunculatum leaf extracts with antibiotics against wound infection associated bacteria," Biological Research, vol. 42, no. 3, pp. 327-338, 2009.

[27] C. E. Oramadike and S. T. Ogunbanwo, "Antagonistic activity of Thymus vulgaris extracts against vibrio species isolated from seafoods," Journal of Food Science and Technology, vol. 54, no. 5, pp. 1199-1205, 2017.

[28] M. V. Eberhardt, C. Y. Lee, and R. H. Liu, "Antioxidant activity of fresh apples,” Nature, vol. 405, no. 6789, pp. 903-904, 2000.

[29] H. Baba and A. Onanuga, "Preliminary phytochemical screening and antimicrobial evaluation of three medicinal plants used in Nigeria," African Journal of Traditional, Complementary and Alternative Medicines, vol. 8, no. 4, 2011. 
[30] T. L. Eberhardt, X. Li, T. F. Shupe, and C. Y. Hse, "Chinese tallow tree (Sapium sebiferum) utilization: characterization of extractives and cell-wall chemistry," Wood and Fiber Science, vol. 39, no. 2, pp. 319-324, 2007.

[31] O. M. Agunloye and G. Oboh, "Effect of different processing methods on antihypertensive property and antioxidant activity of sandpaper leaf (Ficus exasperata) extracts," Journal of Dietary Supplements, vol. 15, no. 6, pp. 871-883, 2018.

[32] J. O. Olugbami, M. A. Gbadegesin, and O. A. Odunola, "In vitro free radical scavenging and antioxidant properties of ethanol extract of Terminalia glaucescens," Pharmacognosy Research, vol. 7, no. 1, p. 49, 2015.

[33] O. B. Shittu, O. L. Ajayi, S. O. Bankole, and T. O. S. Popoola, "Intestinal ameliorative effects of traditional ogi-tutu, Vernonia amygdalina and Psidium guajava in mice infected with Vibrio cholera," African Health Sciences, vol. 16, no. 2, pp. 620-628, 2016.

[34] P. S. Pavithra, V. S. Janani, K. H. Charumathi, R. Indumathy, S. Potala, and R. S. Verma, "Antibacterial activity of plants used in Indian herbal medicine," International Journal of Green Pharmacy, vol. 4, pp. 22-28, 2010.

[35] B. A. R. Hassan, "Medicinal plants (importance and uses)," Pharmaceutica Analytica Acta, vol. 3, no. 10, 2012.

[36] O. A. Aiyegoro and A. I. Okoh, "Use of bioactive plant products in combination with standard antibiotics: implications in antimicrobial chemotherapy," Journal of Medicinal Plants Research, vol. 3, no. 13, pp. 1147-1152, 2009.

[37] R. H. Liu, "Potential synergy of phytochemicals in cancer prevention: mechanism of action," The Journal of Nutrition, vol. 134, no. 12, pp. 3479-3485, 2004.

[38] A. A. Ishola and K. E. Adewole, "Phytosterols and triterpenes from Morinda lucida benth. exhibit binding tendency against class i HDAC and HDAC7 isoforms," Molecular Biology Reports, vol. 46, no. 2, p. 2307, 2019.

[39] A. Adebajo, S. Odediran, F. Aliyu, P. Nwafor, N. Nwoko, and U. Umana, "In vivo antiplasmodial potentials of the combinations of four Nigerian antimalarial plants," Molecules, vol. 19, no. 9, pp. 13136-13146, 2014.

[40] M. Anyanwu and R. Okoye, "Antimicrobial activity of Nigerian medicinal plants," Journal of Intercultural Ethnopharmacology, vol. 6, no. 2, pp. 1-259, 2017.

[41] T. H. Fatoki, O. O. Elekofehinti, A. C. Akinmoladun, and D. M. Sanni, "Functional compounds of Lobelia inflata revealed novel potential targets for chronic cough therapy," Journal of Advances in Medical and Pharmaceutical Sciences, vol. 19, no. 2, pp. 1-13, 2019.

[42] M. O. Daniyan and O. T. Ojo, "In silico identification and evaluation of potential interaction of Azadirachta indica phytochemicals with Plasmodium falciparum heat shock protein 90," Journal of Molecular Graphics and Modelling, vol. 87, 2019.

[43] J. Sacarlal and D. Denning, "Estimated burden of serious fungal infections in Mozambique," Journal of Fungi, vol. 4, no. 3 , p. $75,2018$.

[44] B. Oluremi and J. Adeniji, "Anti-viral activity evaluation of selected medicinal plants of Nigeria against measles virus," British Microbiology Research Journal, vol. 7, no. 5, pp. 218-225, 2015.

[45] J. A. Philips and J. D. Ernst, "Tuberculosis pathogenesis and immunity," Annual Review of Pathology: Mechanisms of Disease, vol. 7, no. 1, pp. 353-384, 2012.

[46] W. H. Lewis, "Pharmaceutical discoveries based on ethnomedicinal plants: 1985-2000 and beyond," Economic Botany, vol. 57, no. 17, pp. 126-134, 2003.
[47] B. Taiwo and O. Igbeneghu, "Antioxidant and antibacterial activities of flavonoid glycosides from ficus exasperata vahlholl (moraceae) leaves," African Journal of Traditional, Complementary and Alternative Medicines, vol. 11, no. 3, pp. 97-101, 2014.

[48] C. Mandengue and D. Denning, "The burden of serious fungal infections in Cameroon," Journal of Fungi, vol. 4, no. 2, p. 44, 2018.

[49] Y. F. Hallock, J. H. Cardellina, M. Schäffer et al., "Korundamine A, a novel HIV-inhibitory and antimalarial "hybrid" naphthylisoquinoline alkaloid heterodimer from Ancistrocladus korupensis," Bioorganic \& Medicinal Chemistry Letters, vol. 8, no. 13, pp. 1729-1734, 1998.

[50] S. Abachi, S. Lee, and H. Rupasinghe, "Molecular mechanisms of inhibition of streptococcus species by phytochemicals," Molecules, vol. 21, no. 2, p. 215, 2016.

[51] O. M. Okwuosa, E. I. Chukwura, G. O. Chukwuma et al., "Phytochemical and antifungal activities of Uvaria. chamae leaves and roots, Spondias mombin leaves and bark and Combretum racemosum leaves," African Journal of Medicine and Medical Sciences, vol. 41, pp. 99-103, 2012.

[52] A. A. Aiyeloja and O. A. Bello, "Ethnobotanical potentials of common herbs in Nigeria: a case study of enugu state," Educational Research and Reviews, vol. 1, pp. 16-22, 2006.

[53] S. Ogbonnia, A. A. Adekunle, M. K. Bosa, and V. N. Enwuru, "Evaluation of acute and subacute toxicity of Alstonia congensis engler (apocynaceae) bark and Xylopia aethiopica (dunal) A. rich (Annonaceae) fruits mixtures used in the treatment of diabetes," African Journal of Biotechnology, vol. 247, pp. 188-192, 2008.

[54] R. O. Oladele, I. I. Osaigbovo, O. O. Ayanlowo, A. A. Otu, and M. Hoenigl, "The role of medical mycology societies in combating invasive fungal infections in low- and middleincome countries: a Nigerian model," Mycoses, vol. 62, no. 1, pp. 16-21, 2019.

[55] O. Okpe, N. Habila, J. Ikwebe, V. A. Upev, S. I. R. Okoduwa, and O. T. Isaac, "Antimalarial potential of Carica papaya and Vernonia amygdalina in mice infected with Plasmodium berghei," Journal of Tropical Medicine, vol. 2016, Article ID 8738972, 6 pages, 2016.

[56] S. D. Ola-Fadunsin and I. O. Ademola, "Anticoccidial effects of Morinda lucida acetone extracts on broiler chickens naturally infected with Eimeria species," Pharmaceutical Biology, vol. 52, no. 3, pp. 330-334, 2014.

[57] M. M. Suleiman, T. Dzenda, and C. A. Sani, “Antidiarrhoeal activity of the methanol stem-bark extract of Annona senegalensis pers. (annonaceae)," Journal of Ethnopharmacology, vol. 116, no. 1, pp. 125-130, 2008.

[58] O. V. Omotoyinbo and M. D. Sanni, "GC-MS analysis of phyto-components from the leaves of Senna alata L," Journal of Plant Sciences, vol. 3, no. 3, pp. 133-136, 2015.

[59] U. Keyal, X. Huang, and A. K. Bhatta, "Antifungal effect of plant extract and essential oil," Chinese Journal of Integrative Medicine, vol. 23, 2016.

[60] R. Barbieri, E. Coppo, A. Marchese et al., "Phytochemicals for human disease: an update on plant-derived compounds antibacterial activity," Microbiological Research, vol. 196, pp. 44-68, 2017.

[61] G. Suleyman and G. J. Alangaden, "Nosocomial fungal infections," Infectious Disease Clinics of North America, vol. 30, no. 4, pp. 1023-1052, 2016.

[62] J. E. Okokon, N. B. Augustine, and D. Mohanakrishnan, "Antimalarial, antiplasmodial and analgesic activities of root 
extract of Alchornea laxiflora," Pharmaceutical Biology, vol. 55, no. 1, pp. 1022-1031, 2017.

[63] M. J. Cheesman, A. Ilanko, B. Blonk, and I. E. Cock, "Developing new antimicrobial therapies: are synergistic combinations of plant extracts/compounds with conventional antibiotics the solution?" Pharmacognosy Reviews, vol. 11, no. 22, p. 57, 2017.

[64] S. T. S. Hassan, K. Berchová, M. Majerová, M. Pokorná, and E. Švajdlenka, "In vitro synergistic effect of Hibiscus sabdariffa aqueous extract in combination with standard antibiotics against Helicobacter pylori clinical isolates," Pharmaceutical Biology, vol. 54, no. 9, pp. 1736-1740, 2016.

[65] R. O. Oladele, Current Status of Serious Fungal Infections in Nigeria, The University of Manchester, Manchester, UK, 2018.

[66] A. A. Olaniyi and J. W. Powell, "Lignans from Justicia flava," Journal of Natural Products, vol. 43, no. 4, pp. 482-486, 1980.

[67] P. C. Iyamah and M. Idu, "Ethnomedicinal survey of plants used in the treatment of malaria in southern Nigeria," Journal of Ethnopharmacology, vol. 173, pp. 287-302, 2015.

[68] M. S. Butler and A. D. Buss, "Natural products-the future scaffolds for novel antibiotics?" Biochemical Pharmacology, vol. 71, no. 7, pp. 919-929, 2006.

[69] S. S. Handa, S. P. S. Khanuja, G. Longo, and D. D. Rakesh, Extraction Technologies for Medicinal and Aromatic Plants, International Centre for Science and High Technology, Trieste, Italy, 2008.

[70] O. A. Conrad, I. P. Dike, and U. Agbara, "In vivo antioxidant assessment of two antimalarial plants-Allamamda cathartica and Bixa orellana," Asian Pacific Journal of Tropical Biomedicine, vol. 3, no. 5, pp. 388-394, 2013.

[71] E. O. J. Ozioma and O. A. N. Chinwe, "Herbal medicines in African traditional medicine," Herbal Medicine, vol. 10, pp. 191-214, 2019.

[72] B. S. Ivana, L. B. P. Mateus, D. V. Antonio, and N. Y. Riad, "Antibacterial activity of Brazilian amazon plant extracts," Brazilian Journal of Infectious Diseases, vol. 10, no. 6, 2006.

[73] S. Subramaniyan, S. Divyasree, and G. Sadasivan Sandhia, "Phytochemicals as effective quorum quenchers against bacterial communication," Recent Patents on Biotechnology, vol. 10, no. 2, pp. 153-166, 2016.

[74] T. C. Okoye, P. A. Akah, C. O. Okoli, A. C. Ezike, E. O. Omeje, and U. E. Odoh, "Antimicrobial effects of a lipophilic fraction and kaurenoic acid isolated from the root bark extracts of Annona senegalensis," Evidence-Based Complementary and Alternative Medicine, vol. 2012, Article ID 831327, 10 pages, 2012.

[75] N. S. Ncube, A. J. Afolayan, and A. I. Okoh, "Assessment techniques of antimicrobial properties of natural compounds of plant origin: current methods and future trends," African Journal of Biotechnology, vol. 7, no. 12, pp. 1797-1806, 2008.

[76] I. A. Oladosu, S. O. Balogun, and G. O. Ademowo, "Phytochemical screening, antimalarial and histopathological studies of Allophylus africanus and Tragia benthamii," Chinese Journal of Natural Medicines, vol. 11, no. 4, pp. 371-376, 2013.

[77] F. Bongomin, S. Gago, R. Oladele, and D. Denning, "Global and multi-national prevalence of fungal diseases-estimate precision," Journal of Fungi, vol. 3, no. 4, p. 57, 2017.

[78] F. Bongomin, R. Kwizera, and D. W. Denning, "Getting histoplasmosis on the map of international recommendations for patients with advanced HIV disease," Journal of Fungi, vol. 5, no. 3, p. 80, 2019.
[79] K. Springbob and T. M. Kutchan, "Introduction to the different classes of natural products," in Plant-erived Natural Products: Synthesis, Function, and Application, V. Lanzotti, Ed., Springer, Berlin, Germany, 2009.

[80] R. N. Okigbo, C. L. Anuagasi, and J. E. Amadi, "Advances in selected medicinal and aromatic plants indigenous to Africa," Journal of Medicinal Plants Research, vol. 3, no. 2, pp. 86-95, 2009.

[81] E. O. Ajaiyeoba, O. O. Ogbole, O. O. Abiodun, J. S. Ashidi, P. J. Houghton, and C. W. Wright, "Cajachalcone: an antimalarial compound from Cajanus cajan leaf extract," Journal of Parasitology Research, vol. 2013, Article ID 703781, 5 pages, 2013.

[82] M. Nishan and P. Subramanian, "Pharmacological and nonpharmacological activity of Azadirachta indica (neem)-a review," International Journal of Biosciences, vol. 6655, pp. 104-112, 2014.

[83] H. A. Odelola and V. I. Okorosobo, "Preliminary investigation of in-vitro antimicrobial activity of two Nigerian diospyros species (ebenaceae)," African Journal of Medicine and Medical Sciences, vol. 17, no. 3, pp. 167-170, 1988.

[84] H. S. Jebashree, S. J. Kingsley, E. S. Sathish, and D. Devapriya, "Antimicrobial activity of few medicinal plants against clinically isolated human cariogenic pathogens-an in vitro study," ISRN Dentistry, vol. 2011, Article ID 541421, 6 pages, 2011.

[85] M. Vambe, A. O. Aremu, J. C. Chukwujekwu, J. F. Finnie, and J. Van Staden, "Antibacterial screening, synergy studies and phenolic content of seven south African medicinal plants against drug-sensitive and resistant microbial strains," South African Journal of Botany, vol. 114, pp. 250-259, 2018.

[86] H. Ugboko, B. Mathew, R. Solomon, E. Omonigbehin, and N. De, "Studies on effects of bark extracts of Azadirachta indica a. (juss) on multidrug resistant Salmonella typhi," Asian Journal of Applied Science and Technology, vol. 7, no. 2, pp. 2325-2332, 2016.

[87] S. R. Lockhart and J. Guarner, "May. Emerging and reemerging fungal infections," in Seminars in Diagnostic Pathology, pp. 177-181, WB Saunders, Philadelphia, PA, USA, 2019.

[88] A. Olaniyi, "Two new arylnaphthalide lignans from Justicia flava roots," Planta Medica, vol. 44, no. 3, pp. 154-156, 1982.

[89] E. O. Agbaje and A. O. Onabanjo, "Toxicological study of the extracts of anti-malarial medicinal plant Enantia chlorantha," Central African Journal of Medicine, vol. 40, no. 3, pp. 71-73, 1994.

[90] B. A. Adeniyi, O. O. Ayepola, and F. D. Adu, "The antiviral activity of leaves of Eucalyptus camaldulensis (dehn) and Eucalyptus torelliana (R. muell)," Pakistan Journal of Pharmaceutical Sciences, vol. 28, no. 5, pp. 1773-1776, 2015.

[91] P. Tiwari, B. Kumar, M. Kaur, G. Kaur, and H. Kaur, "Phytochemical screening and extraction: a review," International Journal of Pharmacy and Pharmaceutical Sciences, vol. 1, no. 1, pp. 98-106, 2011.

[92] B. Nayak, R. H. Liu, J. D. J. Berrios, J. Tang, and C. Derito, "Bioactivity of antioxidants in extruded products prepared from purple potato and dry pea flours," Journal of Agricultural and Food Chemistry, vol. 59, no. 15, pp. 8233-8243, 2011.

[93] G. Boyd, C. Steinert, D. Feineis, V. Mudogo, J. Betzin, and C. Scheller, "HIV-inhibitory michellamine-type dimeric naphthylisoquinoline alkaloids from the central african liana Ancistrocladus congolensis," Phytochemistry, vol. 128, pp. 71-81, 2016. 
[94] X. Han, T. Shen, and H. Lou, "Dietary polyphenols and their biological significance," International Journal of Molecular Sciences, vol. 8, no. 9, pp. 950-988, 2007.

[95] A. O. Ogundare and B. O. Oladejo, "Antibacterial activities of the leaf and barkextract of Persea americana," American Journal of Ethnomedicine, vol. 1, no. 1, pp. 64-71, 2014.

[96] M. S. Meskin, Phytochemicals in Nutrition and Health, CRC Press, Boca Raton, FL, USA, 2002.

[97] M. Saxena, J. Saxena, R. Nema, D. Singh, and A. Gupta, "Phytochemistry of medicinal plants," Journal of Pharmacognosy and Phytochemistry, vol. 1, no. 6, 2013.

[98] A. C. Ogodo and U. G. Ekeleme, "In-vitro antibacterial activity of garlic cloves and ginger rhizomes on foodborne pathogens," International Journal of Basic and Applied Sciences, vol. 2, no. 4, p. 387, 2013.

[99] O. N. Maitera, H. Louis, O. O. Oyebanji, and A. O. Anumah, "Investigation of tannin content in Diospyros mespiliformis extract using various extraction solvents," Journal of Analytical \& Pharmaceutical Research, vol. 7, no. 1, 2018.

[100] O. Ajayi, S. Awala, A. Ogunleye, F. Okogbue, and B. F. Olaleye, "Antimicrobial screening and phytochemical analysis of Elaeis guineensis (ewe igi ope) against salmonella strains," British Journal of Pharmaceutical Research, vol. 10, no. 3, pp. 1-9, 2016.

[101] S. Sasidharan, Y. Chen, D. Saravanan, K. M. Sundram, and L. Y. Latha, "Extraction, isolation and characterization of bioactive compounds from plants' extracts," African Journal of Traditional, Complementary and Alternative Medicines, vol. 8, no. 1, 2011.

[102] M. Idu, S. E. Omonigho, and C. L. Igeleke, "Preliminary investigation on the phytochemistry and antimicrobial activity of Senna alata l. flower," Pakistan Journal of Biological Sciences, vol. 10, no. 5, pp. 806-809, 2007.

[103] A. T. Sheldon, "Antibiotic resistance: a survival strategy," Clinical Laboratory Science, vol. 18, no. 3, p. 170, 2005.

[104] A. S. Kutama, I. I. Dangora, W. Aisha, M. I. Auyo, U. Sharif et al., "An overview of plant resources and their economic uses in Nigeria," Global Advanced Research Journal of Agricultural Science, vol. 4, no. 2, pp. 042-067, 2015.

[105] S. Hemaiswarya, A. K. Kruthiventi, and M. Doble, "Synergism between natural products and antibiotics against infectious diseases," Phytomedicine, vol. 15, no. 8, pp. 639-652, 2008.

[106] O. E. Adebiyi and M. O. Abatan, "Phytochemical and acute toxicity of ethanolic extract of Enantia chlorantha (oliv) stem bark in albino rats," Interdisciplinary Toxicology, vol. 6, no. 3, pp. 145-151, 2013. 